\section{Animal Liberation as a Valid Response to Structural Violence}

\author{
Amy Liszt \\ Mobilization for Animals, e.V. \\ Göttingen, Germany
}

\begin{abstract}
Editors' Note: The following paper by Amy Liszt and the comment on it by Professor Finsen were presented at the Pacific Division meetings of the Society for the Study of Ethics and Animals, held in Los Angeles, California, March, 1990. The preceding month Ms. Liszt also presented her paper at a conference in Berkeley, California-"Animals, Ethics, and Social Policy"-organized by the Schweitzer Center and co-sponsored by the Center for Ethics and Social Policy at the Graduate Theological Union.
\end{abstract}

Wendell Phillips was a passionate crusader against slavery and the suppression of women. The Harvard Law School graduate was known as a gifted orator and essayist. He wrote a letter on the 22nd of April, 1845 to Frederick Douglass, who was then still a fugitive slave. But a mere forty years later Douglass was to become Consul General to the Republic of Haiti.

Phillips wrote in his letter:

One must judge the merits of abolition on other parameters than whether it results in cheaper sugar, and one must hate slavery for other reasons than because slaves may be struck, injured and mutilated.

We must gauge the wretchedness of the slave not by his pain and fatigue, not by his blows and toil but by the cruel and blighting death which gathers over his psyche. That is, we must not pick out the rare or even more frequent specimen of cruelty, nor the incidental aggravations nor the individual ills, but rather that which must mingle always and necessarily

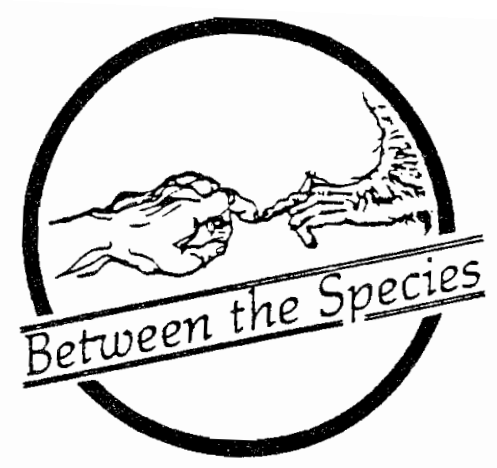

in the lot of every slave in human captivity. These are the essential ingredients, not the occasional results, of the System. ${ }^{1}$

Wendell Phillips clearly recognized and described structural violence without having so named it.

You may have just been mentally substituting the words "farm and experimental animals" for "slaves" as well as "animal rights" for "abolition." With respect to animals we find outselves in a situation today very similar to that of the abolitionists of 1845 .

The liberation of experimental and factory farm animals today, like that of the slaves then, is felt by the liberator to be moral, but is illegal. The circumstances leading to liberation are equally paradoxical, namely, the treatment of victims is felt to be immoral but is legal. The key to these puzzles lies in the nature of structural violence. ${ }^{2}$

Structural violence is a very different sort of violence than the violence which we consciously perceive. If three men, a banker, a merchant, and a factory owner, steal the money and burn down the house of a fourth, he will be ruined. But this is personal violence, as we have always known it. The same three men, moving across societal structures, can accomplish the same thing: the banker calls in his loan, the merchant cuts off his credit, and the factory owner fires him-the result is also ruin. It is not required that these actions be

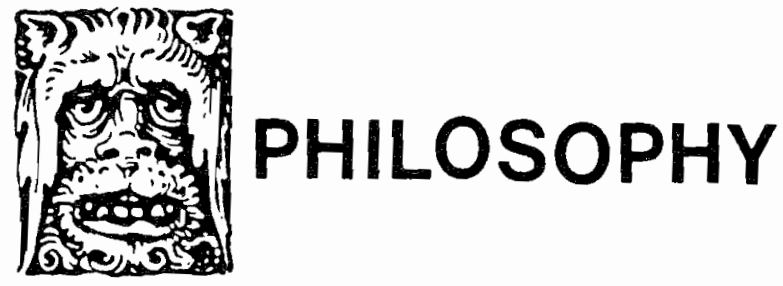


intentional. They may simply be logical steps taken during a period of high interest rates.

The object of personal violence perceives the source of the violence and can attempt to protect himself from it. The object of structural violence can be persuaded to notice nothing at all. The ruined man of our example might say at the end, "These are certainly hard times."

Personal violence is dynamic and characterized by change. Structural violence is static and rigid, like the structures which bear it. And in a static society structural violence is imperceptible. The maintenance of a standing army is quietly accepted by us all, although it is in fact a brutal killing machine. Our society is static. We don't notice the brutality that emanates from our structures.

The discussion of personal violence leaves open the question of who the perpetrator of violence is: the actor in the actor/act/victim relationship is not discussed. In fact, when looking at structural violence, it is not the subjective intention but, rather, the objective consequence which is of primary interest. One grasps the deeper nature of structural violence when it becomes clear that a person can be the agent in a violent act as in the example of the banker and his friends, without being its author. The actor/act/victim/ relationship is broken. There is now only act/victim, only action and that which is acted upon.

To have died of hunger a hundred years ago in Ethiopia, before hunger became dependent upon a world market economy, cannot be considered to have been death caused by structural violence. Today it can be so considered. Today we know that hunger is the result of market mechanisms. We know that there is enough to eat in the world and that this food could be equitably distributed. But although we well-fed Europeans and Americans know what is happening there, and why, the situation appears to be unyielding and the perpetrator of this hunger, the author of this violence, cannot be found. It is a clear case of structural violence.

\section{"Structural violence expresses itself in the unequal distribution of the chances for survival."}

Our moral codes derive from Judeo-Christian concepts of guilt and innocence based on the presence or absence of intent. These concepts of guilt and innocence are useless against impending developments in mass society. Laws which are drawn up to prevent personal or intended violence fail when faced with structural or unintended violence. These laws catch the little fish and let the big ones go free.

Structural violence is an integral part of all the structures of society. Structural violence expresses itself in the unequal distribution of the chances for survival. This violence has no single recognizable author. This violence remains unremarked until its victim is struck.

It is clear, then, that the perpetrator of structural violence is not to be sought. The structures, the System are the culprits, and these must be changed-if there is time.

The strategic question is now, as it was among the abolitionists: should all effort be put into correction or reform of the System? Or do we (or at least some of us) take radical steps to protect the victims? The radical step here under consideration is the forcible removal of laboratory and farm animals from harm, or animal liberation. The philosophical question, and the question considered in this paper, then becomes: if the victims are thus protected, can this act be considered to be valid despite its being illegal?

If we wish to correct the System, we must find means which are appropriate and adequate. The choice of means depends largely on the time felt to be available for reform. Long-term methods center around agitation and education at the grass-roots level. Acute, short-term methods include civil disobedience and sabotage. But if animals are to be protected now from the inherent dangers to them of the System until a hoped-for reform is achieved, they must be removed from harm's way. This paper argues that the liberation of experimental and farm animals is a valid stop-gap measure in the face of injury to and destruction of animals through (unintended) structural violence.

To arrive at a conclusion about the validity of animal liberation as a response to structural violence, we must ask whether it is legitimate, whether it is necessary, and whether it is apt.

\section{Legitimacy}

In respect to the question of legitimacy, or lawfulness, it can be observed that the animal liberator assumes the existence of animal rights and he sees that these are being violated. Like the abolitionist of 150 years ago, she feels compelled to protect the victims of 
a system which she feels to be unjust. The animal liberator, like the abolitionist before him, does not rely on closely reasoned theses. He relies on arguments which are readily accessible to common sense through a minimum of reflection. The process of such argument presupposes the absence of vested interests. It is to these arguments and perceptions of justice that we must speak today. These arguments, in the end, form the basis for the ever more acute perception of right and wrong with regard to human interactions with animals. These arguments will be the motivating force for legislative change.

The well-spring of human rights lies deep in the subjective perception of the individual. It is obvious for each human individual that suffering is an evil and is to be avoided-even more so, arbitary suffering. The victim perceives arbitrary suffering as that suffering which has as its result no perceptible benefit to himself or to those whom he loves. This simple observation is experienced as obvious by every healthy, cognizant individual. It has been codified and made good not only for the individuals doing the codifying but also, by extension and in principle, for all individuals. Animals, of course, have not succeeded in codifying a system of rights for themselves, and they have not been included in the protected circle of beings upon whom these rights are bestowed. But the point of departure is the same, whether for human or animal: that is, the subjective feeling that suffering is an evil and is to be avoided. And animals do avoid suffering when left to themselves. If humans prevent animals from avoiding suffering, or even directly cause animals to suffer, then animal rights are being violated. This fact establishes the legitimacy of intervention for the liberator. He then casts about for means to correct the situation, that is, to restore to the animals their rights which are being violated by law.

The German animal rights legislation of 1972 and 1987 surprisingly underscores the duty of humans to come to the aid of animals in distress. Following clauses in the legislation, however, weaken the original force, since the duty is suspended when the distress is being caused in the name of a "higher good" or a "reasonable purpose." The animal liberator makes the easy jumpand so must we-to the Third Reich. He asks whether we could accept today the silent watching of German citizens while European Jewry, Gypsies, and pacifists were being herded through the streets of Bergen-Belsen, Ravensbrück and Dachau. The prisoners begged for water after the days-long journey passed standing and pressed tightly together in filthy cattle cars. The German citizens watched silently and gave no water, because the suffering of these people had a "reasonable purpose" and was dictated by a "higher good," namely, the purification and salvation of the "Aryan race." We cannot accept the principle of acquiring a "higher good" at the price of forced suffering today, and it was not accepted then. This was the victorious principle at the Nuremberg trials. Despite the dictum "Nulla poena sine leges" (meaning there can be no question of punishment in the absence of laws) the defendants were charged with having followed orders which violated unwritten (until that time) laws protecting human rights.

The inescapable conclusion is that for all time a powerful precedent has been set regarding the inviolability of inherent rights which may not have been formally recognized as such. Intervention on behalf of human rights was praised at Nuremberg. Non-support or active violation of these unwritten human rights was punished-for some with death by hanging.

\section{"Unjust laws exist"}

The legitimacy of intervention in a situation which violates (unwritten) laws, even when unheld by national legislation, was thus secured and must be applicable today in the case of animal liberation.

\section{Necessity}

The legitimacy of breaking bad laws was, of course, recognized long before Nuremberg. In 1776 the right to revolution in the event of tyranny was written into the American constitution. But the necessity for the individual to break bad laws was most eloquently put by Henry David Thoreau in 1849:

It is not a man's duty, as a matter of course, to devote himself to the eradication of any, even the most enormous wrong: He may still properly have other concerns to engage him; but it is his duty at least to wash his hands of it. Unjust laws exist; shall we be content to obey them, or shall we endeavor to amend them, and obey them until we have succeeded, or shall we transgress them at once?...If the injustice is part of the necessary friction of 
the machine of government, let it go, let it go; perchance it will wear smooth-certainly the machine will wear out.... But if it is of such a nature that it requires you to be the agent of injustice to another, then, I say, break the law. Let your life be a counter friction to stop the machine. $^{3}$

Every one of us who pays taxes is an accessory to the crime of depriving experimental animals of their freedom, their well-being and their lives. The animal liberator, having perceived that the liberation of an experimental animal would restore to it its rights, feels the necessity to act to remove the very possibility of injustice itself. An additional press of necessity comes from the realization that an injustice is being compounded by one's forced participation in it. The liberator also acts to remove from himself the burden of complicity in injustice.

The necessity of liberating animals who are at risk of injury or death can be seen to have been established within the more demanding moral framework of the liberator.

\section{Aptness}

To determine whether an act is apt, after having determine that it is legitimate and necesssary, one must make a judgment about both its efficacy in remedying an injustice, and whether the means are commensurate. To do that we must look at what the liberator is up against.

The System is the collection of the means by which we humans organize our society to enable large masses of strangers to live together. The means crystallize over time into formal structures, such as the Department of Education, the Post Office, the telecommunications industry, the Military, the Administration, the sewage system, the Department of Health and Welfare, and the Food and Drug Administration. The System regulates the transportation of goods and raw materials into cities and waste material and finished products out of cities. To the extent that animals fall into these two categories, as food or as the raw material for furs, shoes, soap, cosmetics, and drugs, their fate is intimately bound to the structures of the System.

I would like now to characterize these structures in order to demonstrate the means by which they transport violence, as well as to demonstrate their unusual power to resist change. This will indicate the aptness of animal liberation as a counter-measure.

\section{Structures Thrive in Times of Plenty and Are Associated with Progress in the Minds of the People}

Hunger slows growth. Post-scarcity industrialized people are no longer hungry. The structures thrive. We have not only primary industry, we now have supporting and leisure industries. We have secondary and even tertiary work. Social structures thrive and multiply and reinforce each other through mutually binding laws and the issuance of directives, through intermeshing functions and interconnected funding, and through a massive bureaucratic support system which oversees communications and keeps the machine oiled and running and in good order. But while hunger slows growth, glut creates susceptibility for unrestrained growth. We need only take the example of New York City. There, at the turn of the century, the average speed was 11 miles an hour. After the Second World War the average speed was 43 miles an hour. And today, not despite but because of the continuous increase in motorization, the average speed has fallen to 10.5 miles per hour. This leads to periodic chaos on the streets, endangering waste removal, preventing fire department and police-force efforts, and causing breakdowns in public transportation. These systems verge daily on collapse, and on any given day one system or another is temporarily crippled.

Despite all this, we seem grateful for high GNPs, and we are worried when production is cut back. We love to hear that the number of telephones, televisions, cars, and video recorders is increasing, and sympathize with the poor Irish who have only one telephone for 27 people or the regrettable Italians who have only one car for every five people. It is clearly a case of believing that "more is better" and most is best.

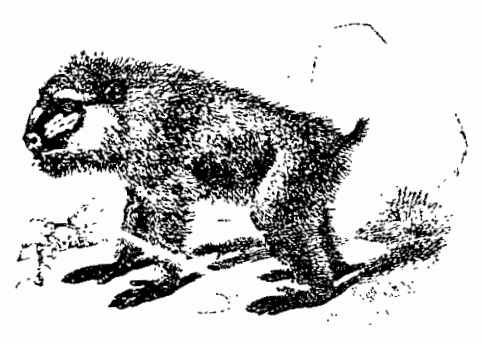




\section{Structures Are Conservative}

Structures resist change through the institution of methods and forms. Patterns of behavior become points of protocol. Over time repeated solutions become traditional ones. It becomes difficult and costly to change. One hears: "It's always been that way."

\section{Structures Are Autonomous}

Structures develop their own lives with their own raison d' être. This "inner life" derives from the peculiar circumstances and requirements of a given structure. Its ramifications oblige the humans who serve it. It prescribes certain courses of action which, once established, cannot be deviated from. One hears: "We have no choice," "Our hands are tied," and "We have our orders."

Structures develop their own ideology which functions in two directions: on the one hand as a defense mechanism directed against criticism and threat from without, and on the other as a motivational force within. A motto is developed which has a hypnotic effect when repeatedly uttered. The motto of the military is "We protect democracy," which serves often enough to mask aggressive efforts. The motto of the church is "We save souls for Christ," while Latin America struggles under the burden of poverty and overpopulation. The motto of science is "We serve humanity," while iatrogenic illness, the potential for nuclear disaster, and the destruction of the natural world continue their dangerous course.

The autonomy of the structures makes humans unresponsive to each other. One hears: "I don't set the wages," and "I don't make the rules."

The autonomy of the structures makes humans unresponsive to their own deeper human needs. One hears: "My work requires doing unpleasant things occasionally," and "There are unpleasant aspects to my job."

The autonomy of the structures dictates the decisions of the decision-makers. As we well know, the man who is about to become President of the United States is a different one than he who has become President. Within twenty-four hours the newly elected president becomes the recipient of classified information from the CIA and FBI, which decidedly affects his decision-making in the future. The office changes the man and not vice versa.
These autonomous structures foster moral indifference in the interchangeable humans who serve the permanent structures. One hears: "If I don't do it, somebody else will."

Structures interrupt the otherwise continuous exchange between human consciousness and the environment. Individual responsibility and conscience are uncoupled from deeds. One hears: "It's the law," and "It's legal." And one hears the classic expression of delegated conscience: "I was only following orders."

\section{Structures Are Ponderous and Insensitive to External Impulse}

Human beings react swiftly and ingeniously to changes in their environment. They seek shelter against wind and rain; they remove clothing when it is hot. A nation, or its bureaucracy, reacts slowly to the environment. By the time the alarm signals from the extemal environment have become massive enough to be registered by various ministries and departments, by the time policy has been drawn up to cope with the problem, the situation has often developed to the point that it is no longer amenable to control. The long-standing building scandals in Mexico City didn't reach national and international attention until 1986, when 20,000 residents died in an earthquake as a result of faulty construction. The various environmental protection agencies and ministries in Europe and America are only now beginning to work seriously on removing the causes of air, water, and ground pollution- now that it is certainly too late to avoid major environmental dislocation. One hears: "Washington hasn't reacted yet," and "We must wait for the Common Market directives."

\section{Structures Have No Method of Self-Reflection}

Structures have limited, built-in screening procedures for efficiency and performance. But there is no possibility of structures rethinking methods and aims. There is no possibility of bringing policy smoothly in line with scientific discoveries or new sensibilities in the overall population. One hears: "Rules are rules."

\section{Structures are Compartmentalized}

There is always a more-or-less clear line drawn between different areas of activity in a bureaucracy. The 
various segments fit more-or-less smoothly together to create the whole. Authority for a certain area goes only so far, then others become responsible for other areas. One hears: "That's not my responsibility," and "We aren't authorized to do that."

\section{Structures Are Multifunctional}

Structures serve several hidden agendas. Authority and hierarchical position are fought over, even though the structures nominally have other functions. Men who had climbed to the top of the hierarchy in the Third Reich had no trouble in post-war Germany achieving similar status. These men enjoy power and influence today at the heights of their uninterrupted careers. It is a game. The agility with which one moves about and within the structures and the strategies with which one wins power and proves superiority are important, and almost nothing else. To maintain the status quo insures maintaining rank. The easiest way to see who is really at the top of the heap is to watch who comes to the defense of a structure which is under attack.

\section{Structures Serve as Symbolic Wish-Fulfillment}

Subconscious attiudes are projected onto structures. Human feelings are lived out in the symbolic form of social policy. Unemployment certainly has something to do with withheld parental praise and reward. Socialized medicine certainly has something to do with parental love and care. Capital punishment has something to do with hate and rage. Psychiatric institutions have something to do with indignation over deviant behavior.

We have briefly described some of the characteristics of structures which explain their predilection to violence, that is, their tendency to transport structural violence, as well as their peculiar resistance to change and reform.

It would be useful now to take a look into the laboratory for a moment in the attempt to determine the aptness of animal liberation as a counter-measure.

A baboon is brought into an operating room. Perhaps it is a laboratory like that of Andrea Kirzinger and Uwe Jürgens in Munich. Perhaps like that of Douglas Rush in Minneapolis. They are all similar. The baboon is fully conscious and strapped into a monkey chair, so that he can't move about. He may have been strapped into the monkey chair over a period of months or years. Electrodes are implanted, which when activated, make porridge out of the area in which they are implanted. The baboon will be injured, say, in the ventro-posterial thalamus, or in the caudo-lateral pons, and shortly thereafter will be killed in order to "minimize suffering," as Kirzinger and Jürgens wrote in $1985 .^{5}$ The animal is dead. It suffered in captivity, it suffered in the experiment, and now it is dead, although it was completely healthy beforehand, and although it had done nothing wrong, and although Kirzinger and Jürgens presumably had nothing against this particular baboon. The baboon had probably also not been able to establish anything like ill-will on the part of his keepers. It had probably even noticed that they occasionally spoke to him and that food and water were always provided for him. The baboon couldn't identify any particular aggressor or enemy who stood behind his suffering. But suffer he did. This baboon is the victim of structural violence. The agent which transported the violence is the structure of science itself. The author of the violence is nowhere to be found.

"No one knows why most of the

important animal merchants in the world are Germans"

To kill a baboon because one doesn't like the sight of him is personal violence and illegal. To kill a million baboons because it makes "brain-mapping" possible counts as good science; it is also structural violence and has remained, until now, legal.

The road which takes the baboon out of the jungle on to the operating table is a journey through many structural instances and a great deal of violence. The hunter who catches him is paid by the head. It would certainly never occur to him that he is doing anything wrong, and even if it did, it wouldn't matter to him because he knows that scientists from Europe and America, who must know what they are doing, have ordered the animal. The hunter says: "If I don't do it, then someone else will." The merchant, perhaps someone like Heini Demmer or Walter Sensen-no one knows why most of the important animal merchants in the world are Germans--knows only the law at the end of the day. Conscience is not a required commodity here, and he knows how he can get around the law if he must. He knows everything there is to know about 
"grey" markets, and that they can dry up, and what to do about it. Heini Demmer and Walter Sensen say: "We don't make the rules" and "It's legal."

The animal that is disoriented, too cold or too hot, thirsty, lonely, frightened, and exhausted is shipped around the world in a crate like a sack of flour. The deck hands, security guards, veterinary doctors and secretaries who shove this crate around, examine its contents, and fill out carrying papers, all say: "I don't make the rules," and "I am only doing my work," and "Sometimes my work has disagreeable aspects." They try to forget what they have seen and done or they don't really notice it. Heini Demmer and Walter Sensen deliver their animal-if it has survived the trip-to a pharmaceutical company like Bayer, or to the Frankfurter Zoo or to the Yerkes Primate Center in Atlanta. There it will be received by a warden. The warden may or may not be concerned about the condition of the animal and about its fate. He says: "Sometimes my work has disagreeable aspects." He tries (or doesn't try) to keep the animal as healthy as possible, depending on the particulars of the institute. He delivers the animal to the operating room and to the scientist who says: "We serve humanity," and "My job has unpleasant aspects." The warden collects the animal after the operation, if it has survived, and will later say: "I was only following orders."

"Freedom which operates by denying freedom is grotesque"

Scientific procedures are refined and improved on the bodies and lives of animals. Scientists say that this is good science, and science must remain free. Animal rights workers say that scientists have abused animals, and that freedom which operates by denying freedom is grotesque.

The structures are solid, securely in place, supported by habit, tradition, money, faulty logic and irrational impulses. They will not yield easily or soon to pressure for reform.

We have made out a great injustice, which cannot be easily righted due to the immense staying power of our institutional structures. The liberation of animals can be seen to be the single most effective and least destructive method of preventing injustice to a specific animal at risk of injury or death. The act must be considered admirably apt. The act of animal liberation, having been demonstrated to be legitimate, necessary and apt, must be regarded as valid.

"The structures are solid, securely in place, supported by habit, tradition, money, faulty logic, and irrational impulses"

The animal liberator, ahead of the society, at odds with the majority, transcends the ordinary instinct of self-preservation for the sake of righting a wrong. Far from being branded a criminal, she must be considered by us to be in a sort of civil state of grace.

\section{Notes}

1 Frederick Douglass, Narrative of the Life of Frederick Douglass. London, 1984, pp. 44-45.

2 For background on the theory of structural violence, see Johan Galtung, Strukturelle Gewalt. (Hamburg, 1975, pp. 9-27).

3 Henry David Thoreau, Walden \& "Civil Disobedience." New York, 1980, pp. 227-229.

4 See also Jacques Ellul, L'ordre technologique (Paris, 1987).

5 Uwe Jürgens and Andrea Kirzinger, "The laryngeal sensory pathway and its role in phonation: $A$ brain lesioning study in the squirrel monkey," Exp. Brain Res. 59: 118-124.

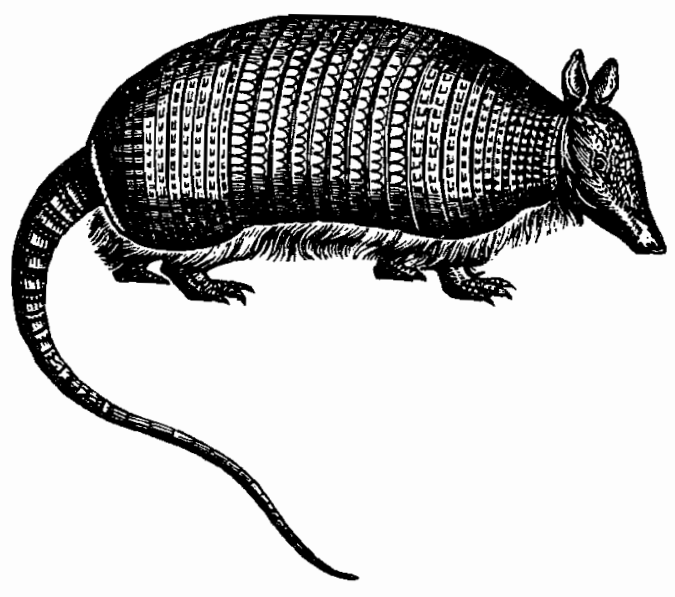

